\title{
Bovine Rectal Myxoma
}

National Cancer Institute

\section{Source}

National Cancer Institute. Bovine Rectal Myxoma. NCI Thesaurus. Code C134768.

A myxoma that occurs in the rectum of a cow. 